\title{
Archaeocyathan limestone blocks of likely Antarctic origin in Gondwanan tillite from the Falkland Islands
}

\author{
P. STONE ${ }^{1,2} \&$ M. R. A. THOMSON ${ }^{3}$ \\ 1. British Geological Survey, Murchison House, West Mains Rd, Edinburgh EH9 3LA, UK \\ (e-mail: psto@bgs.ac.uk)
}

2. Department of Mineral Resources, Ross Road, Stanley, Falkland Islands.

3. School of Earth Sciences, University of Leeds, Leeds LS2 9JT, UK

(e-mail: m.thomson@stone-house.demon.co.uk)

\begin{abstract}
Cambrian limestone clasts containing a rich, well-preserved archaeocyathan fauna have been recovered from the late Carboniferous Fitzroy Tillite Formation of the Falkland Islands. Since neither Cambrian strata nor limestone are present anywhere in the indigenous rock succession, the clasts are regarded as exotic erratics introduced during the Permo-Carboniferous Gondwana-wide glaciation. Most recent reconstructions of Gondwana rotate the Falklands into proximity with the Eastern Cape, South Africa, and the Ellsworth Mountains, Antarctica. In both of these areas, Permo-Carboniferous diamictites correlated with the Fitzroy Tillite Formation also contain rare, exotic clasts of archaeocyathan limestone. The Transantarctic Mountains seem the most likely source for all of these unusual erratics. This interpretation sustains the requirement for substantial rotation of the Falklands microplate into Gondwana reconstructions, and illustrates the extent of the late Carboniferous ice sheet. Apparent differences in the tillite clast assemblages between East and West Falkland suggest variable provenance within the regional ice-flow regime.

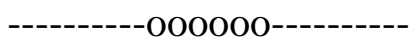

Archaeocyaths are abundant, varied and well-preserved in clasts of massive, grey and white limestone found in late Carboniferous tillite at Port Purvis and Hill Cove, West Falkland (Fig. 1); fragmentary archaeocyaths also occur in clasts of limestone breccia. In East Falkland, rare clasts of sparsely archaeocyathan limestone have been found in the tillite near Mount Pleasant Airport. Archaeocyaths are exclusively Cambrian (Rozanov \& Debrenne 1974) but the Falkland Islands sedimentary sequence is 
entirely post-Cambrian, whilst the entire succession is devoid of limestone (Aldiss \& Edwards 1999). Hence the limestone clasts are likely to be far-travelled erratics introduced into the Falklands area during the late Carboniferous glaciation that affected wide areas of the Palaeozoic Gondwana supercontinent prior to its Mesozoic fragmentation. This paper provides an introduction to the archaeocyathan fauna but concentrates on the significance of its likely provenance in the context of Gondwanan glaciation and palaeogeography.

In reconstructions of Gondwana the Falklands microplate is generally rotated through almost $180^{\circ}$ and placed off the east coast of South Africa (e.g. Adie 1952; Marshall 1994; Storey et al. 1999; Trewin et al. 2002) in proximity to East Antarctica and the Ellsworth Mountains microplate. One such reconstruction is shown in Fig. 2 in a polar projection after Powell \& Li (1994). There is also a consensus that the sedimentary sequence preserved in the Falkland Islands is representative of those adjacent and once-continuous parts of the Gondwana supercontinent now fragmented into South America, Africa and Antarctica. Particularly close stratigraphical similarities are seen between the Falkland Islands and the Cape Fold Belt and Karoo Basin of Southern Africa (e.g. Aldiss \& Edwards 1999; Trewin et al. 2002; Hunter \& Lomas, 2003).

In the Falkland Islands, conjecturally Silurian to unequivocally Devonian, marine but near-shore clastic rocks of the West Falkland Group (Aldiss \& Edwards 1999; Hunter \& Lomas, 2003) form the lower part of the sedimentary succession and rest unconformably on a Precambrian crystalline basement, the Cape Meredith Complex. The West Falkland Group is succeeded by the Carboniferous to Permian, mainly marine to lacustrine clastic strata of the Lafonia Group (Aldiss \& Edwards 1999; Trewin et al. 2002). At the base of the Lafonia Group is a glacigenic unit, the Fitzroy Tillite Formation. Limestone is notably absent from the entire succession.

\section{The Fitzroy Tillite Formation}

The Fitzroy Tillite Formation (the Lafonian Tillite in older literature) is the representative in the Falkland Islands of the late Carboniferous to early Permian glacigenic diamictite that is widespread across the fragments of Gondwana, recording a glacial episode about 290 million years ago (Veevers \& Powell 1987). Gondwana began to break up about 200 million years ago and continental fragments were 
dispersed around the Southern Hemisphere, each fragment with its own part of the once-contiguous tillite succession: the Dwyka Tillite in South Africa, the Sauce Grande Formation in Ventania, Argentina, and the Whiteout Conglomerate in the Ellsworth Mountains, Antarctica. The broad correlation between these different sequences is well established (e.g. Caputo \& Crowell 1985; Matsch \& Ojakangas 1992).

The Fitzroy Tillite Formation of the Falkland Islands (Fig. 1) has recently been reviewed and formally defined by Aldiss \& Edwards (1999). A comprehensive earlier study by Frakes \& Crowell (1967) related lithological differences between East and West Falkland to different depositional environments, as follows. In the west, a brown, sandy mudstone matrix contains and supports a variety of exotic rock clasts, mostly as small pebbles but ranging up to boulders $7 \mathrm{~m}$ across; this is regarded as a terrestrial, sub-glacial deposit. In the east, a dark grey and fine-grained muddy matrix contains a sparse assemblage of clasts that tend to be smaller and of a more restricted lithological range than is seen in the west; the East Falkland tillite was probably deposited in marine conditions under a floating ice sheet.

Whatever the precise depositional process, the clasts in the Fitzroy Tillite Formation were derived from a wide range of rock types. They were carried into the Falklands area of Gondwana by ice, having been eroded from original sources that may have been some considerable distance away. The most common clast types are quartzite, sandstone, various granites, quartz and shale; previously reported accessory types include gneiss, dolerite, slate, porphyry, limestone, chert and conglomerate (Halle 1912; Baker 1924; Frakes \& Crowell 1967; Aldiss \& Edwards 1999). From our recent work, this list can be expanded to include garnet-mica schist, ignimbrite, banded ironstone, and a much wider range of hypabyssal igneous types than was indicated by the previous designation of “porphyry”. Not all clasts are necessarily exotic and some Skolithos-bearing sandstone blocks could have been derived from the underlying Port Stephens Formation.

The limestone clasts contained in the tillite are relatively rare overall but in West Falkand appear to be concentrated at certain localities. In the Hill Cove section for example, limestone clasts were only found at the eastern end; there they are relatively abundant with 22 of the 25 clasts examined in detail proving to contain archaeocyaths. Further, archaeocyathan limestone clasts appear to be rarer in East Falkland than in West Falkland. Although limestone is a widespread accessory in the 
East Falkland tillite only 2 limestone clasts have been found to contain archaeocyaths (out of 15 examined in detail). In the West Falkland clasts the archaeocyaths were commonly visible macroscopically, whereas in the East Falkland clasts the archaeocyaths were only discovered in thin section.

Apart from the archaeocyaths described here, the authors know of only one other possible example of a limestone clast containing macrofossils: a cobble of crinoid-bearing limestone, found loose on West Falkland and held privately, probably came from the tillite although its reported location is not close to any known tillite outcrop (pers. com. Richard Cockwell 2002). If both limestone types did indeed come from the tillite they demonstrate further the lithological range of its clasts, since the archaeocyathan limestone must be Cambrian whereas crinoids did not appear widely until post-Cambrian times. In East Falkland the only additional, and rather tentative organic traces so far found are ooids in a clast recently collected from Mount Pleasant, East Falkland (BGS specimen LX1003); the ooids may have had an algal component to their formation (Davis et al. 1978).

Other qualitative differences are also apparent between the tillites of East and West Falkland, quite apart from the well-defined facies contrast: the lithological and size range of the clasts is much greater in the west than in the east; clasts in the west are generally more rounded than those in the east; in the west there is a much higher proportion of red granite and quartzite, relative to white varieties. Additionally, the apparent concentration of archaeocyathan limestone clasts at a few localities in West Falkland, rather than their being randomly distributed, is a feature that may have broad stratigraphical and palaeogeographical implications.

\section{The archaeocyaths}

Archaeocyaths are extinct organisms with a long history of phylogenetic uncertainty but a current consensus that they were closely related to the sponges (Hill 1972; Rowland 2001). They had a calcareous skeleton commonly consisting of two cones, one inside the other and connected by a variety of vertical and horizontal lamellar structures. They lived in a tropical, shallow water $(<100 \mathrm{~m})$ environment. Fossil archaeocyaths typically range in size, in both diameter and length, from less than 1 $\mathrm{mm}$ up to about $5 \mathrm{~cm}$, although lengths of over $50 \mathrm{~cm}$ have been recorded. The first examples appeared about 530 million years ago during the Early Cambrian and 
archaeocyaths then diversified rapidly into hundreds of species that were important contributors to the construction of early marine reefs. Despite their success they were a relatively short-lived group and were extinct before the end of the Cambrian, less than 25 million years after their first appearance. In contrast, other families of sponges that also appeared in the Cambrian are still represented today, over 500 million years later.

The most striking of the archaeocyathan limestone clasts was also the first to be found, at Gladstone Bay, an inlet at the western end of Port Purvis (Fig. 1). Its discovery early in 2002 by Judith Clay and Sue Macaskill, whilst they were on holiday from the UK, was entirely fortuitous (Stone \& Rushton 2003), but Clay and Macaskill recognized its appearance as highly unusual and arranged for it to be sent on to the Department of Mineral Resources in Stanley for identification. It was found loose but resting on outcrop of the Fitzroy Tillite Formation, and wind-abraded surfaces reveal the archaeocyaths in great detail (Fig. 3). This clast now forms part of the display collection of the Department of Mineral Resources, Stanley, Falkland Islands (Specimen number PS218). The original discovery provoked a systematic search by one of the authors (PS) with more than 20 archaeocyathan limestone clasts subsequently collected in situ from the tillite at Fox Point, to the east of Hill Cove, West Falkland, and two collected in situ from the tillite at Frying Pan Quarry, near Mount Pleasant Airport, East Falkland. These specimens (numbers prefixed PS303 and PS304) are currently held by the British Geological Survey for further study and, hopefully, formal identification.

The Port Purvis clast (Fig. 3) is crammed with fragments and apparently more or less whole specimens of archaeocyaths in a finely crystalline limestone matrix. Cups are of solitary individuals, slenderly conical to cylindro-conical in form, and up to a little over $2.5 \mathrm{~cm}$ in diameter. Transverse sections are circular or suboval; all visible cups are double-walled, the intervallar spaces have radial septa and the central cavities appear to be empty. No lateral outgrowths are visible. The presence and arrangement of mural pores cannot be determined, but there are ragged fragments of test on the clast showing densely packed alternating rows of pores.

At least three different species appear to be present and there are numerous small transverse sections with few septa that might be distinct species, or merely represent the early stages of the larger forms. A preliminary description and further illustrations of the Port Purvis archaeocyaths, based entirely on the naturally occurring 
sections, form Appendix 1. In addition to the archaeocyaths, intricately curved shell fragments seen in cross-section are almost certainly derived from trilobites.

\section{Clast provenance}

Archaeocyaths are restricted to Cambrian limestones (Rozanov \& Debrenne 1974). There are no rocks of that age or that lithology within the Falkland Islands rock succession. The archaeocyathan limestone clasts in the Fitzroy Tillite are therefore exotic to the Falklands and were transported into the area by ice during the latest Carboniferous to earliest Permian glacial episode that produced the tillite deposits. Frakes \& Crowell (1967) derived an overall ice flow direction of west to east (in modern coordinates) from lateral facies changes within the Fitzroy Tillite Formation. This becomes approximately south to north after rotating the Falklands microplate into a Permo-Carboniferous reconstruction of Gondwana (Fig. 2) where it is in line with ice-flow patterns deduced from South Africa (Crowell \& Frakes 1972) and is indicative of ice flow from what is now East Antarctica.

In East Antarctica, archaeocyathan limestone is present in situ at several localities in the Transantarctic Mountains (Laird \& Bradshaw 1982; Debrenne \& Kruse 1986 and 1989; Buggisch \& Henjes-Kunst 1999) and as loose material in recent moraines at Whichaway Nunataks (Hill 1965); illustrated species appear similar to those in the Falklands clasts. The specimens collected at Whichaway Nunataks (during the 1957 Trans-Antarctic Expedition) are now housed in The Natural History Museum, London, and show a macroscopic similarity between their limestone lithology and that of some white limestone clasts from Hill Cove.

In West Antarctica, limestone blocks containing archaeocyaths (albeit much smaller varieties than are seen in the Falklands example) have been recovered from the Whiteout Conglomerate of the Ellsworth Mountains (Debrenne, 1992). That conglomerate is the local representative of the Permo-Carboniferous, Gondwanan tillite and hence the time-stratigraphical equivalent of the Fitzroy Tillite Formation. Although archaeocyaths are also known from in situ Cambrian limestone in the Ellsworth Mountains (Buggisch \& Webers 1992), they are somewhat unusual irregularians that apparently persisted into the Late Cambrian (Debrenne et al. 1984) and are very different species to those recovered from the Whiteout Conglomerate. 
Thus the examples from the Whiteout Conglomerate most probably have an exotic source.

A closer analogy to the Falkland Islands' situation is seen in the Dwyka Tillite, South Africa, where rare archaeocyathan limestone clasts have also been recorded and Antarctica proposed as the most likely provenance (Cooper \& Oosthuizen 1974; Debrenne 1975; Oosthuizen 1981; Visser at al. 1986) since archaeocyaths are otherwise unknown in the region. Curiously, one of the examples illustrated by Visser et al. (1986) from the Dwyka Tillite (op.cit. Fig. 6b) has the broad central cavity and narrow rim of widely spaced septa, somewhat reminiscent of one of the examples from Port Purvis illustrated in Fig. 3. So far as the authors are aware, there are no records of archaeocyaths from the Argentine representative of the Late Carboniferous Gondwana tillite, the Sauce Grande Formation of the Sierras Australes, nor any substantiated reports of in situ archaeocyaths from Cambrian strata in Argentina.

The Transantarctic Mountains area (Fig. 2) would seem to be the most likely source of the archaeocyathan limestone clasts in the Fitzroy (Falkland Islands) and Dwyka (South Africa) tillites, and also of those in the stratigraphically-equivalent Whiteout Conglomerate (Ellsworth Mountains, West Antarctica). Archaeocyathan limestone has been described from several different localities and stratigraphical levels (Debrenne \& Kruse 1989; Wood et al. 1992) with the fauna from the Shackleton Limestone formally described by Hill (1964) and by Debrenne \& Kruse (1989). The Shackleton Limestone host lithology is described by Hill as "massive grey limestone” and among the taxa present is Thalamocyathus, which is also well represented in erratic faunas from Antarctica and South Africa and is possibly also present in the Port Purvis grey limestone clast (see Appendix 1). The Transantarctic Mountains would also seem to be the most likely original source of the Whichaway Nunataks moraine samples and of the ice-rafted archaeocyathan-limestone clasts found at the Atlantic periphery of Antarctica: by dredging in the Weddell Sea (Gordon 1920) and on King George Island, South Shetlands, in Oligocene tillites (Troedson and Riding 2002; Troedson and Smellie 2002) and in recent moraines (Morycowa et al. 1982; Wrona \& Zhuravlev 1996).

\section{Regional significance}


The discovery of archaeocyathan limestone clasts in the Fitzroy Tillite Formation, Falkland Islands, bears significantly on several aspects of the regional geology.

\section{Archaeocyath palaeobiology}

Archaeocyaths are not common in the Southern Hemisphere, with extensive faunas described only from Antarctica and Australia. Since the likely source of the Falkland Islands clasts is the Transantarctic Mountains, the fossils contained in them may expand the Antarctic archaeocyathan faunal record once the systematic description of the specimens from Hill Cove is complete.

\section{Extent of the Permo-Carboniferous ice-sheet}

The Falklands clasts are mostly found in a terrestrial glacigenic lithofacies (Frakes \& Crowell 1967). With a likely source in the Transantarctic Mountains (Fig. 2), this would indicate that the Late Carboniferous, Gondwana ice sheet flowed from the contemporary polar region to almost $60^{\circ}$ south, at least, before becoming glaciomarine. Whilst a large ice sheet with these dimensions is accepted in most palaeogeographical proposals (e.g. Scotese et al. 1999), it is not supported by recent work in the Transantarctic Mountains themselves (Isbell et al. 2003). Further work on the Falklands clasts may help resolve this apparent contradiction.

\section{Glacial facies relationships}

Facies interpretations of the successions in the Ellsworth Mountains (Matsch \& Ojakangas 1992, p. 59), suggest that those of the Whiteout Conglomerate represent environments extending from the ice-sheet grounding line (Meyer Hills) into the open sea (Sentinel Range). Significantly, the glacio-marine facies is represented in the Falkland Islands by that part of the Fitzroy Tillite Formation that is farthest from Antarctica in the Figure 2 reconstruction of Gondwana, implying a terrestrial to glacio-marine transition across the Falklands microplate. In this respect the South African record is complicated by migration of multiple ice dispersal centres and consequential likelihood of clast re-working (Crowell \& Frakes 1972; Caputo \& Crowell 1985; Visser et al. 1986).

One hitherto unexplored feature of the facies relationships between the Fitzroy Tillite Formation in East and West Falkland is the difference in the clast assemblages. This includes the apparently greater absolute number of archaeocyathan limestone 
clasts in the terrestrial facies of West Falkland relative to the glacio-marine facies of East Falkland, and the higher proportion of clasts carrying archaeocyaths within the total limestone population in West Falkland relative to East Falkland. If the terrestrial, late Carboniferous ice sheet did flow from the Transantarctic Mountains to the Falklands areas of Gondwana, it may then have merged with a glacio-marine ice sheet sourced in an entirely different area.

\section{Gondwana reconstructions}

In a reconstruction of Gondwana (Fig. 2), the coincidence of ice flow patterns between the Falkland Islands and South Africa (Adie 1952; Frakes \& Crowell 1967) is now strengthened by the occurrence of the unusual, archaeocyathan limestone clasts in both areas. This adds further credibility to those break-up interpretations that require a substantial rotation of the Falklands microplate (e.g. Marshall 1994; Storey et al. 1999; Trewin et al. 2002), as incorporated in Figure 2.

The apparent contrast between East and West Falkland in Fitzroy Tillite clast assemblages may also be relevant to discussion of the areas' structural assembly. Several authors (e.g. Marshall 1994; Thomas et al. 1997) have suggested that East and West Falkland were juxtaposed by major strike-slip movement along a large fault coincident with Falkland Sound. This would allow the contrasting glacigenic facies, with their different erratic clast assemblages, to be brought together tectonically (though Curtis and Hyam (1998) have argued from structural evidence against such large-scale movement), but would also preclude the use of their present relationships in any large-scale reconstructions.

Acknowledgements: Thanks are due to the following for discussion and advice on various aspects of this paper and for reviews of its earlier manifestations: Don Aldiss, Peter Flood, John Isbell, Bob Thomas, Nigel Trewin, Adrian Rushton and an anonymous referee, clearly an archaeocyath specialist, whose comments were most helpful. In addition, Adrian Rushton kindly arranged access to the Whichaway Nunataks samples in The Natural History Museum, London. We thank Dra Susana Damborenea for advice on aspects of Argentine geology. PS publishes by permission of the Executive Director, British Geological Survey, NERC, and thanks Mrs P. Rendell, Director, Department of Mineral Resources, Stanley, for her support. 


\section{Appendix 1: Descriptions of archaeocyaths from a limestone clast in the Fitzroy Tillite Formation, Port Purvis, Falkland Islands}

The following descriptions are based on examination of the hand-specimen only. The identifications suggested are preliminary and are based only on general similarities to illustrated specimens. Informally, three species are recognised.

\section{Species 1}

Transverse sections of species 1 are more or less circular (Fig. 4a, b) and up to 17.3 $\mathrm{mm}$ in diameter. They are characterised by a wide intervallar space with a proportionally narrow central cavity (about half of the cup diameter), and numerous thin radial septa in the intervallar space. The appearance of densely packed septa is strengthened because of the insertion of septa from the outer wall (Fig. 4c). Septal counts for a half circle on the best specimen (Fig. 4b) are approximately 35 on the inner wall and 48 on the outer wall, or 70 and 96 per full circle, respectively. From the sections available for study, it is not clear whether or not the septa are porous, although this would normally be expected to be the case.

The specimen seen in longitudinal section (Fig. 5a) probably also belongs to species 1 . The section lies slightly to one side of the median plane. It is approximately $80 \mathrm{~mm}$ long, with a maximum width of $19 \mathrm{~mm}$. Septa are closely spaced and crossed by a series of numerous closely spaced tabulae, giving a grid-like pattern to the internal mould. The tabulae are more or less flat, although there are indications in places that some curve slightly against the internal wall and all curve more strongly against the external wall. The skeleton of the present archaeocyaths has been preferentially weathered compared to the matrix and a toothed structure to the infill between the tabulae (Fig. 5e) probably represents pore infills, although it is not possible to discern the arrangement of the pores.

A close match with species 1 is yet wanting. However, because the tabulae appear to curve down to form the outer wall (Fig. 5e), it is possible that the species is a member of the Coscinocyathina. 


\section{Species 2}

The second species is distinguished by having a relatively narrower intervallum and a correspondingly wider central cavity than species 1 (Figs 4a, \& 5a, b, c). Available transverse sections are typically sub-oval, although this might possibly be because they are slightly oblique to the axis of the cup. In addition, the septa have the appearance of being more widely spaced than in species 1 , but a septal count (n) of 120 for the largest specimen with a maximum diameter (D) of $22 \mathrm{~mm}$ actually gives almost the same septal index $(n / D=5.5)$ as species $1(n / D=5.6)$. Septal pores are visible in a few places and these seem to be aligned between adjacent septa. Oblique sections (4d, e) of medium-sized specimens that probably belong to this species suggest that tabulae are not present, or at least are not developed to the same degree as in species 1. In places, on the individual in Fig. 5b, where alternate septa meet the internal wall, short hair-like spinose structures, protruding from the inner wall into the central cavity, are visible. In all cases these are sharply deflected in the same direction on either side of the central cavity to extend at a shallow angle to the wall; at the 'top' and 'bottom' of the transverse section there is a thin line of test concentric with the inner wall. Some of the 'spines' have short beak-like projections on the outer angle of the bend. On the largest specimen (Fig. 4a) hook-like 'spines' appear to emanate from a position corresponding approximately to the intersection of alternate septa with the inner wall, but on a narrowly ovate specimen (Fig 5c, d) probably representing a more oblique section, they are proportionately shorter and more numerous, with one per septum and another one or even two between the 'septal' ones. At the 'top' of the oval section, several lines of concentric structure are visible. All of these 'spine'-like structures and accompanying lines of concentric structure, on the inner face of the inner wall, appear to correspond to a variety of sections through annulae on the inner wall.

There are several specimens that seem to be almost longitudinal sections through smaller examples of species 2, the best being those in Figs 4d \& e. The example in Fig. 4d is a section through a narrow cup with a curved axis. The lower part is close to a true transverse section and shows radial septa around a central cavity, the middle part passes along the intervallum and shows longitudinal lines marking the septa, whereas the top part is narrowly oblique to the median plane of the cup, clearly showing the arrangement of septa and annuli. The example in Fig. 4e, however, is 
more difficult to interpret. The lower part is much abraded but the upper part compares closely with Fig $4 \mathrm{~d}$ and appears to be a section through a cup with a curved or undulating axis. The sharp demarcation between the lower and upper halves could suggest that we are looking either at a branched cup or at a narrow cup with an acute bend in the middle.

At first sight, the largest specimen shown in Fig. 4a and another enlarged in Fig. 4b bear a superficial resemblance to Ladaecyathus fortiseptatus (Hill 1965, pl. V, fig. 2) from Whichaway Nunataks, Antarctica, but neither that species nor the genus are characterized by the annulae of the present specimens. A more likely affinity is with species of Thalamocyathus, widely described and illustrated in situ from the Lower Cambrian of South Australia and Shackleton Limestone of Antarctica (Hill 1964), from 'recent' erratic blocks from the Weddell Sea (Gordon 1920, pl. II, fig 18) and Whichaway Nunataks (Hill 1965, pl. VII , especially figs 2, 3), and from erratic blocks in the Carboniferous Dwyka Tillite of South Africa (Debrenne 1975, fig. 1b, c).

\section{Species 3}

At least two oblique sections (Fig. 4f \& g) through a possible third species appear on the reverse, more degraded side of the clast. Both are relatively small (10 mm or less) and characterised by an intervallar space broken up into narrowly ovate or tear-shaped sections. Narrowly ovate sections extend more or less radially from the inner to the outer wall, but where tear-shaped sections are present, they are two or three deep between the two walls. Both specimens are rather badly worn and it is difficult to be sure what the structure is. Two possibilities come to mind. One is that these represent undulose oblique cross sections through species 1 , i.e. a section that varies between those seen in Figs $4 \mathrm{~b}$ and $5 \mathrm{a}$. The second is that we are looking at sections through forms with taeniae, rather than septa, such as Flindersicyathus Bedford and Bedford, well illustrated from Whichaway Nunataks, Antarctica by Hill (1965, pl. XI, especially figs 1a, 2a \& b, 7a, 8a) or even unrelated forms, such as Syringocnema (cf. Hill 1965, pl. XI, figs 17, 18).

\section{References}


Adie, R. J. 1952. The position of the Falkland Islands in a reconstruction of Gondwanaland. Geological Magazine, 89, 401-410.

Aldiss, D. T. \& Edwards, E. J. 1999. The Geology of the Falkland Islands. British Geological Survey Technical Report, WC/99/10.

Baker, H. A. 1924. Final Report on Geological Investigations in the Falkland Islands, 1920-1922. Government Printer, Stanley.

Buggisch, W. \& Henjes-Kunst, F. 1999. Stratigraphy, facies and provenance analyses of the Lower Cambrian Mount Wegener Formation of the Shackleton Range, Antarctica. Terra Antarctica, 6, 211-228.

Buggisch, W. \& Webers, G. F. 1992. Facies of Cambrian carbonate rocks, Ellsworth Mountains, West Antarctica. In: Webers, G.F., Craddock, C. \& Splettstoesser J.F. (eds) Geology and Paleontology of the Ellsworth Mountains, West Antarctica, Geological Society of America Memoir, 170, 81-89.

Caputo, M. V. \& Crowell, J. C. 1985. Migration of glacial centers across Gondwana during Paleozoic Era. Geological Society of America Bulletin, 96, 1020-1036.

Cooper, M. R. \& Oosthuizen, R. 1974. Archaeocyathid-bearing Erratics from Dwyka Subgroup (Permo-Carboniferous) of South Africa, and their importance to Continental Drift. Nature, 247, 396-398.

Crowell, J. C. \& Frakes, L. A. 1972. Late Palaeozoic Glaciation: Part V, Karroo Basin, South Africa. Geological Society of America Bulletin, 83, 2887-2912.

Curtis, M. L. \& Hyam, D. M. 1998. Late Palaeozoic to Mesozoic structural evolution of the Falkland Islands: a displaced segment of the Cape Fold Belt. Journal of the Geological Society, London, 155, 115-129.

Davis, J. D., Bubela, B. \& Ferguson, J. 1978. The formation of ooids. Sedimentology, 25, 703-730. 
Debrenne, F. 1975. Archaeocyatha provenant de blocs erratiques des tillites de Dwyka (Afrique de Sud). Annals of the South African Museum, 67, 331-361.

Debrenne, F. 1992. The archaeocyathan fauna from the Whiteout Conglomerate, Ellsworth Mountains, West Antarctica. In: Webers, G.F., Craddock, C. \& Splettstoesser J.F. (eds) Geology and Paleontology of the Ellsworth Mountains, West Antarctica. Geological Society of America Memoir, 170, 279-284.

Debrenne, F. \& Kruse, P. D. 1986. Shackleton Limestone archaeocyaths. Alcheringa, 10, 235-278.

Debrenne, F. \& Kruse, P. D. 1989. Cambrian Antarctic archaeocyaths. In: Crame, J. A. (ed.) Origins and Evolution of the Antarctic Biota. Geological Society, London, Special Publication, 47, 15-28

Debrenne, F., Rozanov, A Yu. \& Webers, G.F. 1984. Upper Cambrian Archaeocyatha from Antarctica. Geological Magazine, 121, 291-299.

Frakes, L. A. \& Crowell, J.C. 1967. Facies and paleogeography of Late Paleozoic Diamictite, Falkland Islands. Geological Society of America Bulletin, 78, 37-58.

Gordon, W. T. 1920. Scottish National Antarctic Expedition, 1902-4: Cambrian organic remains from a dredging in the Weddell Sea. Transactions of the Royal Society of Edinburgh, 52, 681-714.

Halle, T. G. 1912. On the geological structure and history of the Falkland Islands. Bulletin of the Geological Institution of the University of Uppsala, 11, 115-229.

Hill, D. 1964. Archaeocyatha from the Shackleton Limestone of the Ross System, Nimrod Glacier area, Antarctica. Transactions of the Royal Society of New Zealand, 2, 137-146. 
Hill, D. 1965. Archaeocyatha from Antarctica and a review of the phylum. TransAntarctic Expedition Scientific Reports, 10, 151 pp.

Hill, D. 1972. Treatise on Invertebrate Paleontolgy, Part E (revised), 1 Archaeocyatha. Teichert, C. (ed.) $2^{\text {nd }}$ edition, 1. Boulder, Colorado and Laurence, Kansas: The Geological Society of America and The University of Kansas, 158 pp.

Hunter, M. A. \& Lomas, S. A. 2003. Reconstructing the Siluro-Devonian coastline of Gondwana: insights from the sedimentology of the Port Stephens Formation, Falkland Islands. Journal of the Geological Society, London, 160, 459-476.

Isbell, J. L., Lenaker, P. A., Askin, R. A., Miller, M. F. \& Babcock, L. E. 2003. Reevaluation of the timing and extent of late Paleozoic glaciation in Gondwana: Role of the Transantarctic Mountains. Geology, 31, 977-980.

Laird, M. G. \& Bradshaw, J. D. 1982. Uppermost Proterozoic and Lower Palaeozoic Geology of the Transantarctic Mountains. In: Craddock, C. (ed) Antarctic Geoscience. Madison: The University of Wisconsin Press, 525-533.

Marshall, J. E. A. 1994. The Falkland Islands: a key element in Gondwana palaeogeography. Tectonics, 13, 499-514.

Matsch, C. L. \& Ojakangas, R. W. 1992. Stratigraphy and sedimentology of the Whiteout Conglomerate: an Upper Paleozoic glacigenic unit, Ellsworth Mountains, West Antarctica. In: Webers, G.F., Craddock, C. \& Splettstoesser J.F. (eds) Geology and Paleontology of the Ellsworth Mountains, West Antarctica. Geological Society of America Memoir, 170, 37-62.

Morycowa, E., Rubinowski, Z \& Tokarski, A. K. 1982. Archaeocyathids from a moraine at Three Sisters Point, King George Island (South Shetland Islands, Antarctica). Studia Geologica Polonica, 74, 73-80.

Oosthuizen, R. D. F. 1981. An attempt to determine the provenance of the southern Dwyka from palaeontological evidence. Palaeontologica Africana, 24, 27-29. 
Powell, C. McA. \& Li, Z.X. 1994. Reconstruction of the Panthalassan margin of Gondwanaland. In: Veevers, J. J. \& Powell C. McA. (eds) Permian - Triassic Pangean basins and foldbelts along the Panthalassen margin of Gondwanaland. Geological Society of America Memoir, 184, 5-9.

Rowland, S. M. 2001. The Archaeocyathan Enigma Solved? Journal of Paleontology, 75, 1065-1078.

Rozanov, A. Yu. \& Debrenne, F. 1974. Age of Archaeocyathid assemblages. American Journal of Science, 274, 833-848.

Scotese, C. R., Boucot, A. J. \& McKerrow, W. S. 1999. Gondwanan palaeogeography and palaeoclimatology. Journal of African Earth Sciences, 28, 99-114.

Stone, P. and Rushton, A.W. A. 2003. Some new fossil records and notabilia from the Falkland Islands. Falkland Island Journal, 8 (2), 1-10.

Storey, B. C., Curtis, M. L., Ferris, J. K., Hunter, M .A. \& Livermore, R. A. 1999. Reconstruction and break-out model for the Falkland Islands within Gondwana. Journal of African Earth Sciences, 29, 153-163.

Thomas, R.J., Jacobs, J. \& Weber, K. 1997. Geology of the Mesoproterozoic Cape Meredith Complex, West Falkland. In: Ricci, C.A. (ed.) The Antarctic Region: Geological Evolution and Processes, Terra Antarctica Publication, Siena. 21-30.

Trewin, N. H., Macdonald, D. I. M. \& Thomas, C. G. C. 2002. Stratigraphy and sedimentology of the Permian of the Falkland Islands: lithostratigraphic and palaeoenvironmental links with South Africa. Journal of the Geological Society, London, 159, 5-19.

Troedson, A. L. \& Riding, J. B. 2002. Upper Oligocene to lowermost Miocene strata of King George Island, South Shetland Islands, Antarctica: stratigraphy, facies 
analysis, and implications for the glacial history of the Antarctic Peninsula. Journal of Sedimentary Research, 72, 510-523.

Troedson, A. L. \& Smellie, J. L. 2002. The Polonez Cove Formation of King George Island, Antarctica: stratigraphy, facies and implications for mid-Cenozoic cryosphere development. Sedimentology, 49, 277-301.

Veevers, J. J. \& Powell, C. McA. 1987. Late Palaeozoic glacial episodes in Gondwanaland reflected in transgressive-regressive depositional sequences in Euramerica. Geological Society of America Bulletin, 98, 475-487.

Visser, J. N. J., Hall, K. J. \& Loock, J. C. 1986. The application of stone counts in the glacigene Permo-Carboniferous Dwyka Formation, South Africa. Sedimentary Geology, 46, 197-212.

Wood, R. A., Evans, K. R. \& Zhuravlev, A. Yu. 1992. A new post-early Cambrian archaeocyath from Antarctica. Geological Magazine, 129, 491-495.

Wrona, R. \& Zhuravlev, A. Yu. 1996. Early Cambrian archaeocyaths from glacial erratics of King George Island (South Shetland Islands), Antarctica. Palaeontologia Polonica, 55, 9-36.

\section{Figure captions}

1. Outline geology of the Falkland Islands, showing the outcrop of the Fitzroy Tillite Formation, after Aldiss and Edwards (1999).

2. Reconstruction of Gondwana for the late Carboniferous, in polar projection after Powell and Li (1994). Ice-flow directions from Frakes and Crowell (1967) for the Falkland Islands, and from Crowell and Frakes (1972) for South Africa.

3. A wind-abraded limestone clast from the Fitzroy Tillite Formation at Port Purvis, showing transverse sections through archaeocyaths. The 2-pence coin 
has a diameter of $2.5 \mathrm{~cm}$. Department of Mineral Resources, Stanley, specimen number PS218.

4. Archaeocyaths in a limestone clast, Fitzroy Tillite Formation, Port Purvis, West Falkland.

a. General view of clast, showing sections through species 1 and 2; (x 2)

b. $\quad$ Transverse section of Species 1; (x 2.5)

c. Detail of Fig. 1b, to show septal insertions; (x 7)

d. Longitudinal section of Species 2; (x 2)

e. Longitudinal section through another specimen of Species 2; (x 2)

f. Oblique transverse section through Species 3; (x 3)

g. Oblique transverse section through another specimen of Species 3; (x 3)

5. Archaeocyaths in a limestone clast, Fitzroy Tillite Formation, Port Purvis, West Falkland.

a. General view of another face of the clast, showing a longitudinal section through Species 1 (right), and a transverse-section through Species 2 (top left); (x 2)

b. Transverse section of Species 2; (x 2.5)

c. Oblique section through Species 2, showing annulae; (x 4)

d. Detail of Fig. 1c to show annuli (x 8)

e. Detail of longitudinal section of Species 1, to show porous tabulae; (x 2) 


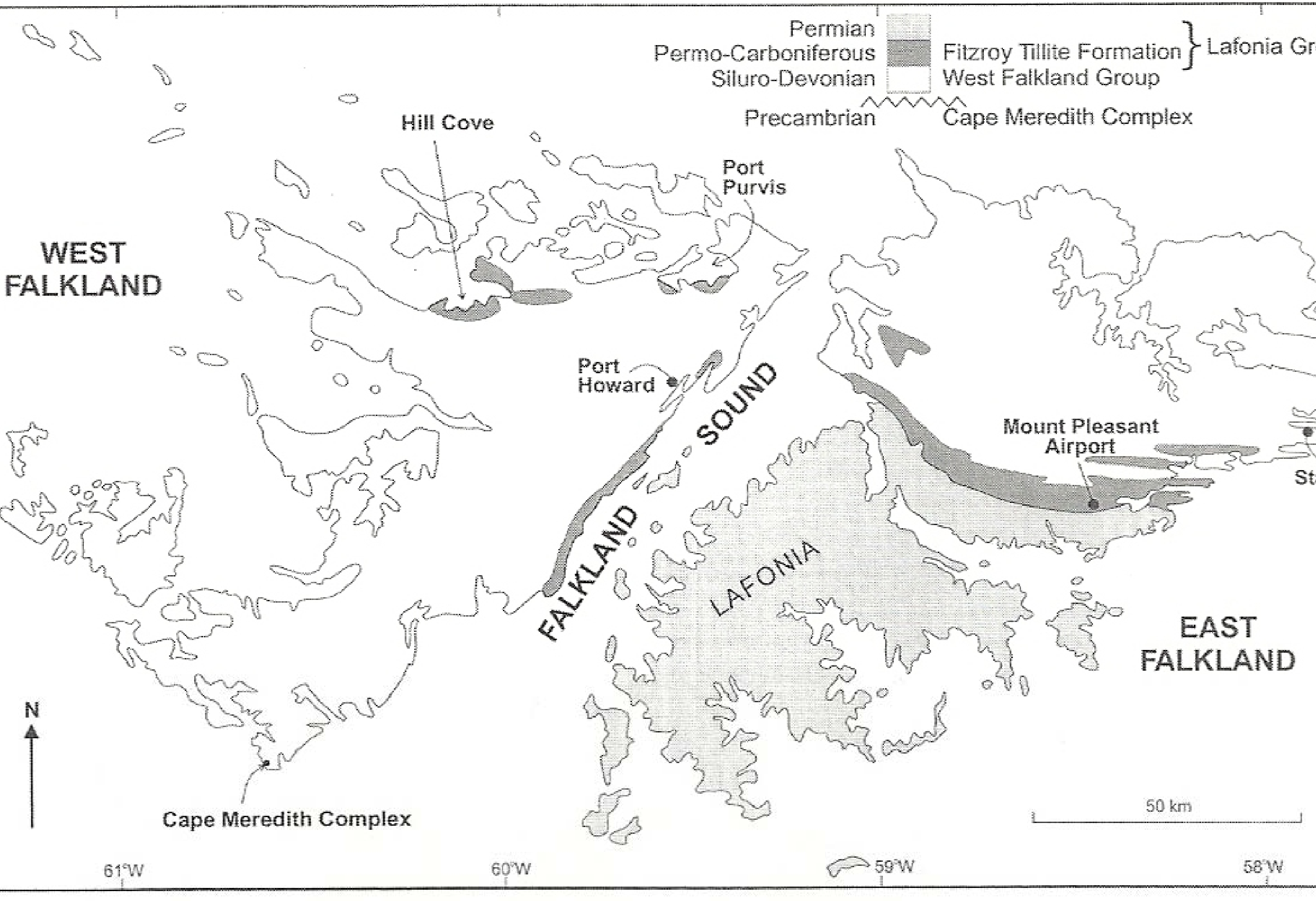




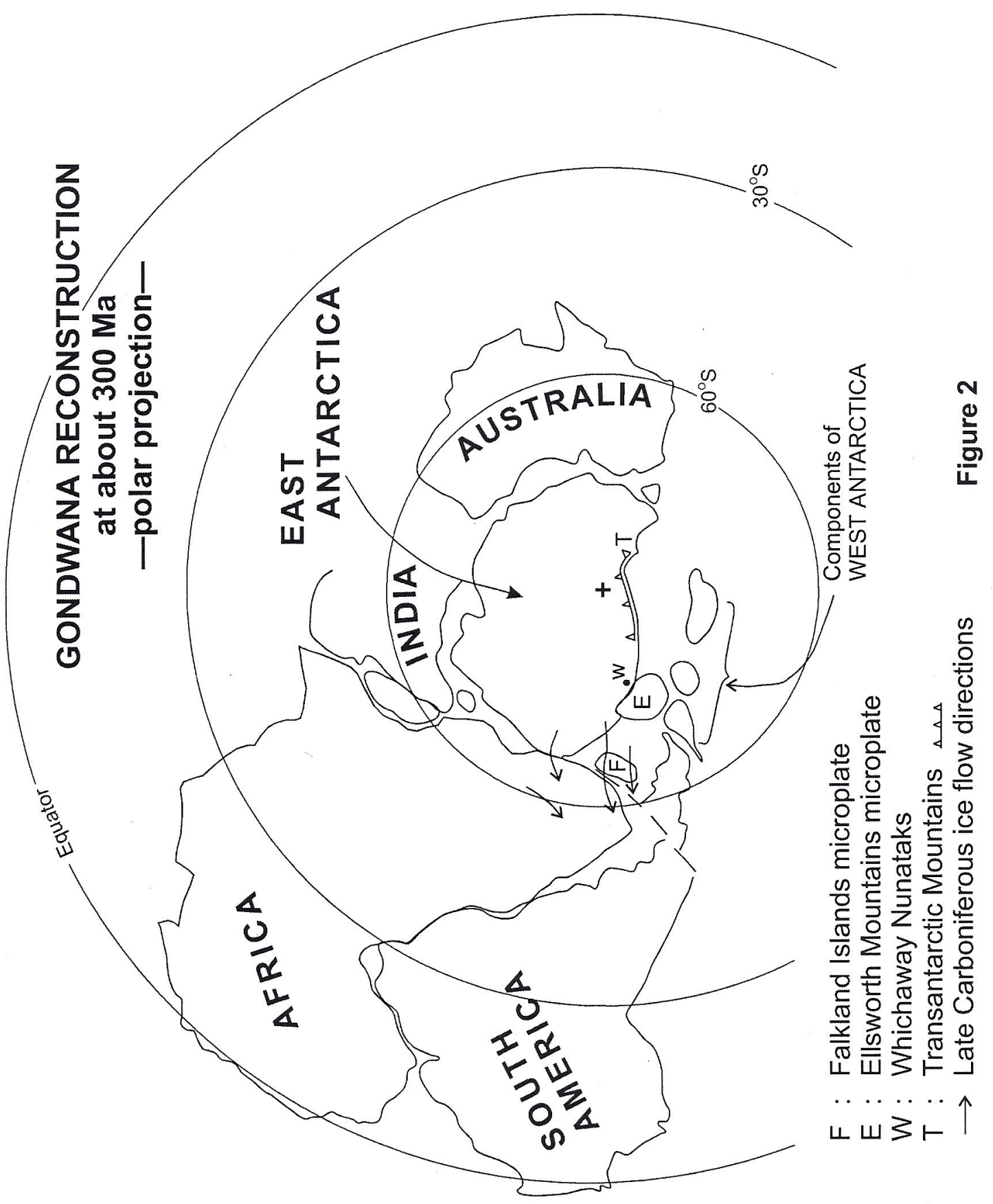




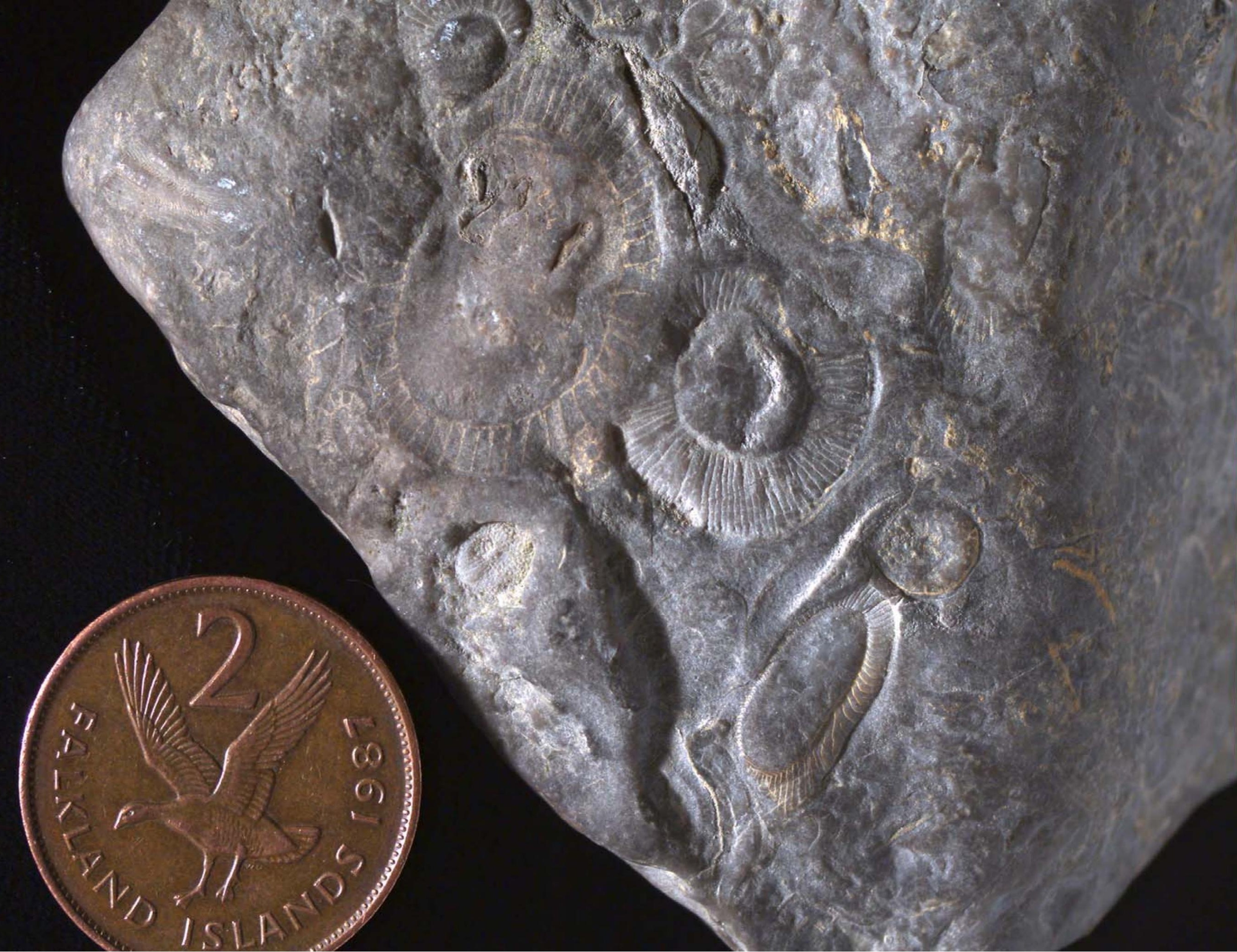


$14-5$ page width FIGURE 5

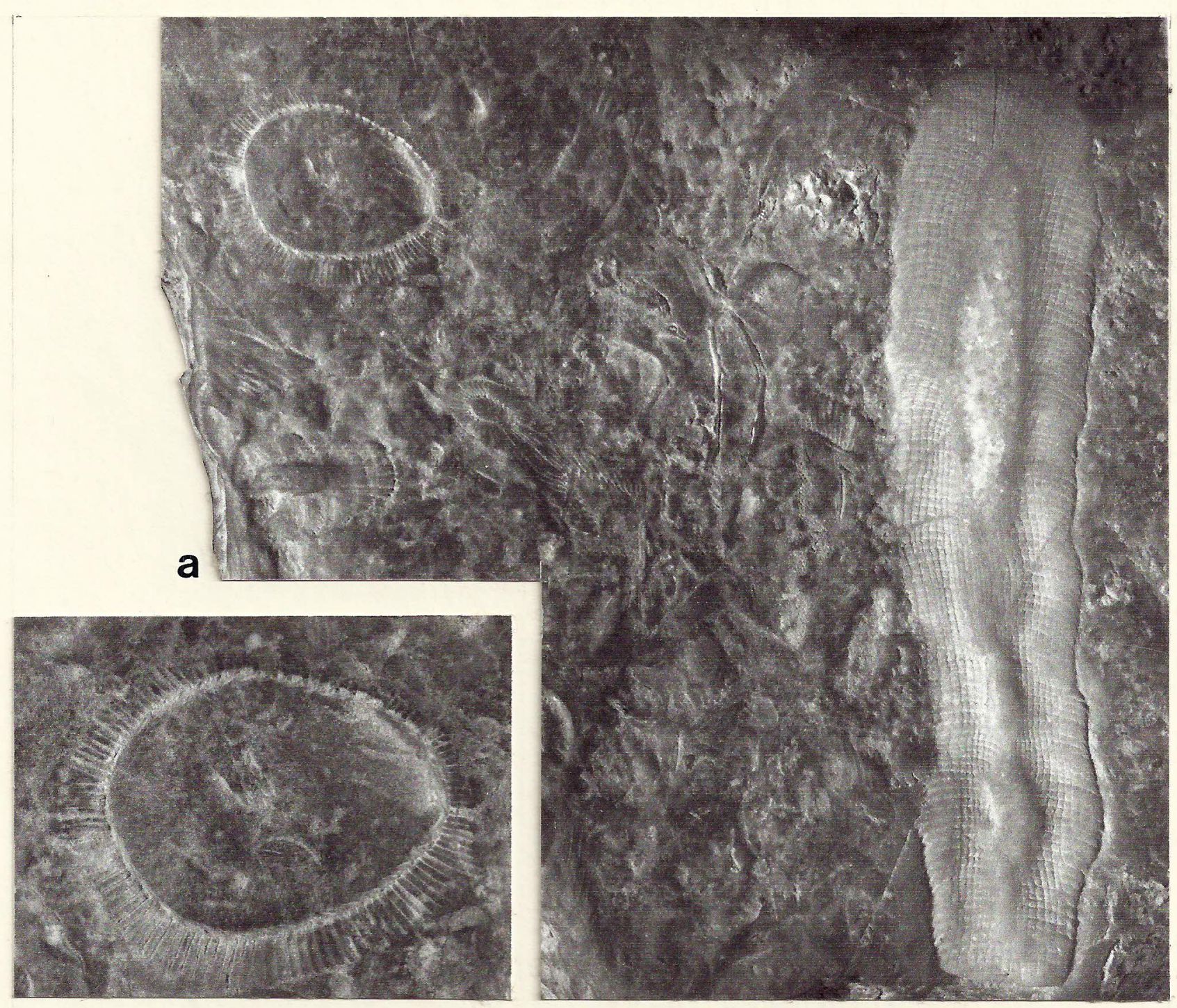

b

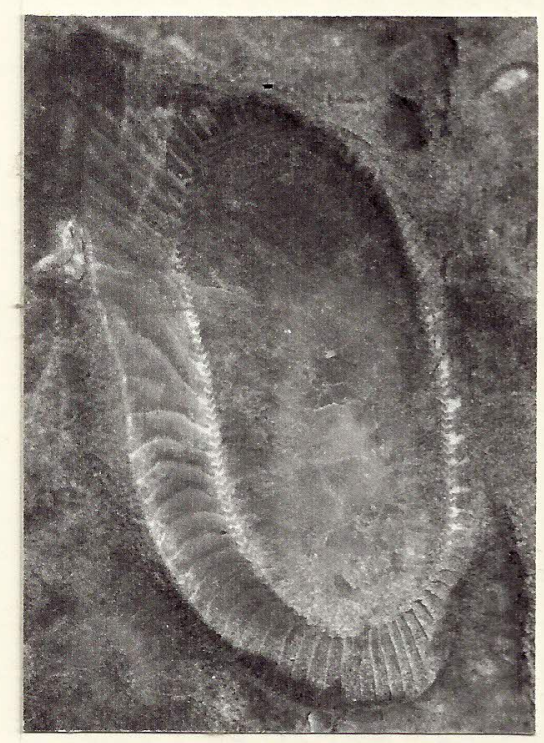

C

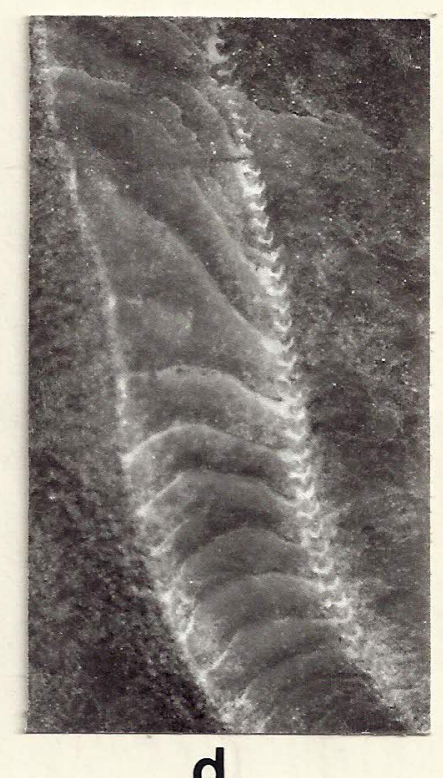

d

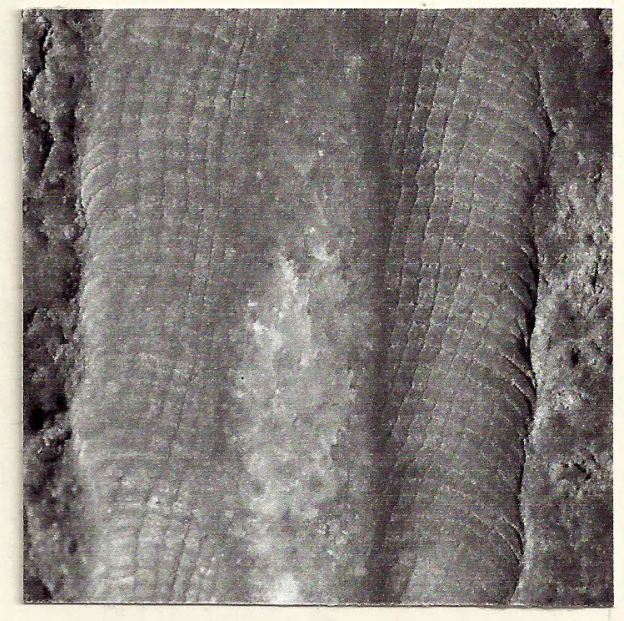

e 
14-4 page widh FGGURE 4
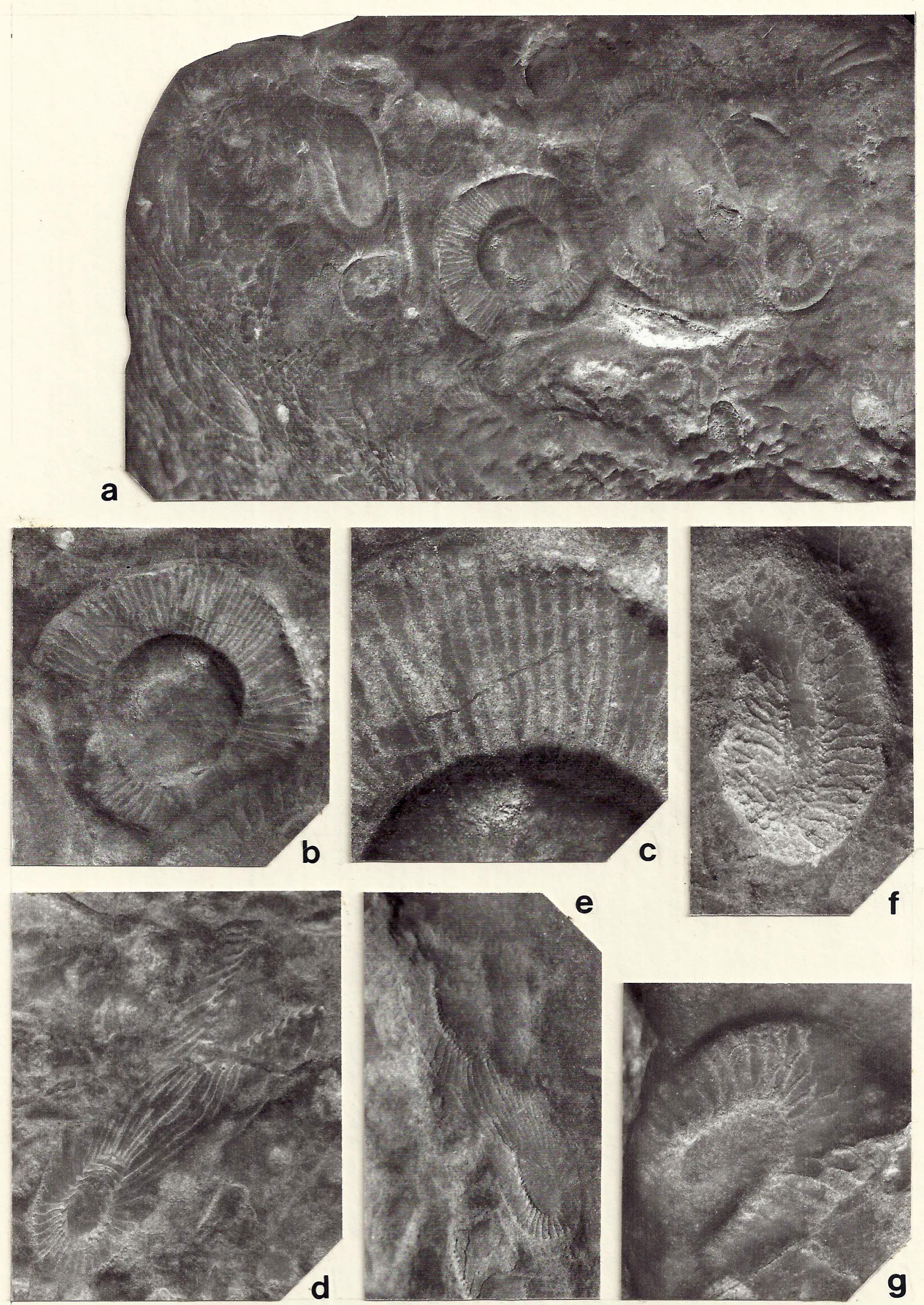

STONE \& THOMSON - FIGURE 4 